\title{
WANPRESTASI PERJANJIAN PERJALANAN WISATA LUAR NEGERI OLEH WISATAWAN INDONESIA
}

\author{
Putri Kusuma Sanjiwani $^{1}$, Luh Putu Kerti Pujani ${ }^{2}$ \\ ${ }^{1}$ Email : kusumasanjiwani@unud.ac.id \\ Program Studi Destinasi Pariwisata, Fakultas Pariwisata Universitas Udayana \\ ${ }^{2}$ Email : kerti_pujani@unud.ac.id \\ Program Studi Destinasi Pariwisata, Fakultas Pariwisata Universitas Udayana
}

\begin{abstract}
The development of tourism, supported by a breakthrough in the development of industry 4.0 , has brought great changes to people in all parts of the world.Tourism is a secondary need for millennial today. They have different motivations individually towards the destination they dream of. People who buy overseas travel packages in travel agents have an escape mode by separating themselves from the tour group at certain destinations. The writing method used in this study is empirical legal research methods supported by primary and secondary data with data collection techniques carried out by observation, interviews, and literature studies.The form of default carried out by Indonesian tourists is classified as doing something in an agreement that is prohibited/ cannot be done.Defaults are made by tourists who will separate themselves from the group and disappear during the tour.They do not return to the hotel or appear within 24 hours so they can be declared lost and reported missing. This activity can broaden the image of the Unitary State of Indonesia in general and the image of travel agents in particular.There needs to be coordination between the community, the government and businessmen of travel agents in suppressing the practices or activities of illegal immigrants.
\end{abstract}

\begin{abstract}
Abstrak: Perkembangan pariwisata yang didukung terobosan perkembangan industri 4.0 telah membawa perubahan besar manusia di seluruh belahan dunia. Pariwisata menjadi kebutuhan sekunder bagi kaum milenial saat ini. Mereka memiliki motivasi berbeda-beda secara individu menuju destinasi tujuan yang mereka mimpikan. Oknum yang membeli paket perjalanan wisata luar negeri di travel agent memiliki modus melarikan diri dengan cara memisahkan diri dari rombongan tour di destinasi tertentu. Mereka berniat menjadi pekerja ilegal atau imigrant gelap. Metode penulisan yang digunakan dalam penelitian ini adalah metode penelitian hukum empiris di dukung dengan data primer dan sekunder dengan teknik pengumpulan data dilakukan dengan observasi, wawancara, serta studi kepustakaan. Bentuk wanprestasi yang dilakukan oleh wisatawan Indonesia tergolong melakukan sesuatu di dalam perjanjian yang dilarang/tidak boleh untuk dilakukan. Wanprestasi dilakukan dengan cara wisatawan akan memisahkan diri dari rombongan dan menghilang pada saat tour. Mereka tidak kembali ke hotel maupun muncul dalam 24 jam sehingga dapat dinyatakan hilang dan dilaporkan hilang. Kegiatan ini dapat membahayan citra Negara Kesatuan Indonesia secara umum dan citra travel agent pada khususnya. Perlu adanya koordinasi antara masyarakat, pemerintah dan pengusaha travel agent dalam menekan praktik atau kegiatan imigran gelap tersebut.
\end{abstract}

Keywords: travel industry, agreement, tourism law. 


\section{PENDAHULUAN}

Berlibur keluar negeri merupakan gaya hidup sebagian besar masyarakat di Indonesia pada zaman milenial ini. Adanya akun sosial media menarik antusias dan motivasi masyarakat untuk melakukan perjalanan keluar negeri, khususnya menuju negara yang memiliki hubungan bilateral dengan Indonesia dan membebaskan visa bagi Warga Negara Indonesia, seperti negara-negara di ASEAN. Perkembangan revolusi industri 4.0 telah membuat dunia mampu digenggam oleh masyarakat tanpa batas waktu (24 jam). Kegiatan berupa observasi dan reservasi dapat dilakukan kapan saja dan dimana saja.

Masyarakat di Indonesia di golongkan dalam dua tipe perencanaan perjalanan wisata, yaitu perencanaan perjalanan wisata mandiri dan kedua perencanaan perjalanan wisata dengan membeli paket wisata di travel agent. Bagi mereka yang membeli paket perjalanan wisata luar negeri di travel agent, rata-rata adalah masyarakat yang kurang mampu dalam berbahasa asing, minim pengalaman traveling ke luar negeri dan masyarakat yang padat dengan kegiatan sehingga tidak sempat merencanakan perjalanan wisata mereka.

Travel agent Indonesia membuat paketpaket menarik dengan harga yang terjangkau bagi calon pembeli jasa perjalanan mereka.Perbedaan musim di Indonesia dan negara yang memiliki empat musim memberikan sensasi yang berbeda dan nilai prestige bagi mereka di sosial media.

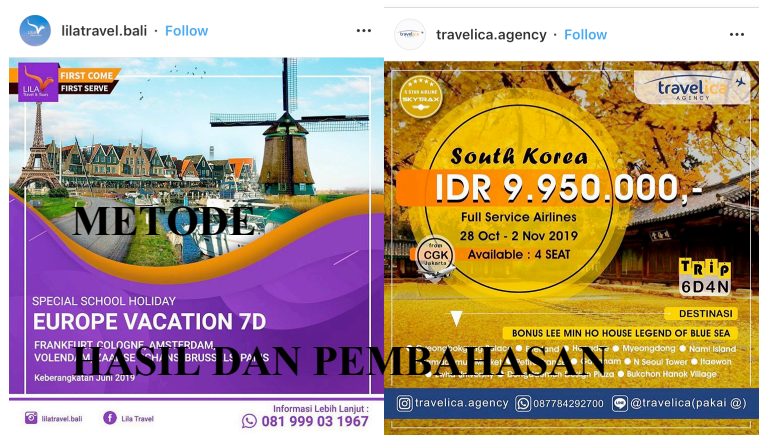

Gambar 1. Bentuk Promosi Travel Agent melalui Sosial Media

Pesona dan daya pikat kehidupan masyarakat di luar negeri, khususnya pada negara-negara maju di dunia membuat banyak orang terpukau. Generasi muda memiliki antusias yang tinggi untuk melanjutkan jenjang bachelor degree atau master degree di negaranegara tersebut. Masyarakat di negara-negara berkembang mencoba mengadu nasib di negara-negara maju. Salah satu contoh, negara Canada membuka pintu seluas-luasnya bagi para imigran untuk bekerja dan menetap di negara tersebut dengan alasan negara Canada minim jumlah penduduk dan tidak seimbang dengan luas negara mereka.

Usaha travel agent tidak hanya sekedar menjual jasa, tetapi menjual kepercayaan. Citra sebuah travel agent akan mempengaruhi kemajuan dan penurunan usaha. Resiko dalam usaha jasa travel agent cukup besar, salah satu bentuk resiko adalah travel agent menjadi sasaran empuk bagi orang-orang yang memiliki misi tertentu dalam pembelian paket perjalanan wisata. Misi tersebut adalah mereka ingin tinggal dan hidup di negara tujuan. Bagi mereka yang tidak mampu memperoleh visa berkeja di negara tujuan, mereka akan melakukan tindakan-tindakan melanggar hukum bahkan mencederai perjanjian perjalanan yang telah mereka beli dari travel agent. Mereka melakukan potong kompas dengan mengajukan visa wisatawan untuk dapat masuk ke negara tujuan yang mereka inginkan.

Sebuah permasalahan akan menjadi fenomena apabila terjadi berulang kali dan menjadi sebuah hal yang rentan terjadi di masyarakat sehingga menjadi perilaku sosial yang dianggap biasa untuk dilakukan. Permasalahan yang diangkat dalam tulisan ini adalah bagaimana bentuk wanprestasi perjanjian perjalanan wisata antara travel agent dengan wisatawan Indonesia yang melakukan perjalanan wisata ke luar negeri? Tujuan penulisan adalah untuk mengkaji serta menganalisis fenomena permasalahan pariwisata yang timbul di masyarakat sehingga dapat dievaluasi dan memberikan solusi terhadap permasahalah tersebut.

\section{METODE}

Metode penulisan yang digunakan dalam penelitian ini adalah metode penelitian hukum empiris. Pendekatan yang digunakan untuk mengkajifaktor-faktor sosial yang mempengaruhi pelaksanaan Peraturan. Penelitianhukum empiris data primer berupa kasus-kasus dilapangan dan didukung dengan data sekunder berupa bahan hukum primer seperti peraturan perundang-undangan, serta bahan hukum sekunder berupa penjelasan 
mengenai bahan hukum primer, buku, artikel yang bersumber dari internet, jurnal hukum, tesis ataudisertasi yang berhubungan dengan penulisan ini. Teknik pengumpulan data dilakukan dengan observasi, wawancara, serta studi kepustakaan.

\section{HASIL DAN PEMBAHASAN Bentuk Wanprestasi Perjanjian Perjalanan Luar Negeri}

Pariwisata merupakan salah satu jembatan penghubung antara satu negara dengan negara lainnya. Hubungan diplomasi bidang pariwisata akan memberikan pengaruh yang cukup kuat pada perkembangan ekonomi negara. Hubungan diplomasi terdiri dari 2 tipe yaitu (Andri Hadi, 2009) :

1. Soft Diplomacy, adalah diplomasi dalam bentuk penyelesaian secara damai dalam bidang kebudayaan, bahasa, persahabatan, ekonomi, dan lain sebagainya.

2. Hard Diplomacy, adalah diplomasi dalam bentuk perang, yaitu agresi militer dan politik.

Bidang kebudayaan dalam soft diplomacy mencakup Pariwisata di dalamnya. Bentuk luaran dari diplomasi pariwisata adalah kemudahan Warga Negara Indonesia dalam melakukan perjalanan ke luar negeri seperti diplomasi antara Indonesia dengan negara ASEAN sehingga negara-negara yang tergabung dalam ASEAN melakukan perjalanan tanpa visa (bebas visa).

Hubungan diplomasi Negara Kesatuan Republik Indonesia dengan Negara Korea Selatan dan Negara Jepang yang memberikan kemudahan terhadap Warga Negara Indonesiadalam memperoleh visa apabila melakukan multiple trips.Kebijakan diplomasi negara-negara di Eropa yang tergabung dalam Uni Eropa (UE), memberlakukan Visa Schengen bagi wisatawan yang ingin mengunjungi Benua Eropa. Visa Schengen berlaku pada 22 negara dari 27 negara yang tergabung di dalam Uni Eropa (UE).

Hubungan diplomasi Negara Kesatuan Republik Indonesia yang semakin meluas dan mendapat kepercayaan yang semakin tinggi dari negara-negara di belahan dunia lainnya, membuat angka perjalanan wisata luar negeri meningkat. Travel agent Indonesia mengambil momentum tersebut seiring dengan perubahan gaya hidup masyarakat milenial dalam bepergian ke luar negeri. Momentum ini juga digunakan oleh oknum-oknum yang tidak bertanggungjawab dalam memenuhi ego atau mimpi mereka.

Pada saat membeli paket perjalanan wisata, pemenuhan administrasi seperti passport, visa, asuransi dan lain-lain wajib untuk dilengkapi oleh calon pembeli jasa sebelum membeli paket wisata. Perjanjian untuk produk dan jasa dari paket wisata dibuat oleh travel agent dan wajib untuk ditandatangani oleh kedua belah pihak sebelum atau sesudah transaksi pembayaran paket wisata. Perjanjian menjadi bentuk perikatan bagi kedua belah pihak yang mengikatkan diri sehingga memiliki kewajiban untuk memenuhi prestasi dari sebuah perjanjian. Menurut KUH Perdata pada pasal 1131 dan 1132, prestasi dapat berupa harta/benda bergerak maupun tidak bergerak. Travel agent memiliki prestasi dalam menyediakan dan melaksanakan perjalanan wisata sedangkan wisatawan sebagai pembeli paket wisata memiliki prestasi untuk mengikuti seluruh rangkaian perjalanan wisata tersebut.

Pemenuhan prestasi dalam perjanjian perjalanan wisata luar negeri tidaklah mudah, perilaku wisatawan maupun travel agent yang buruk dapat mencederai perjanjian. Cukup banyak wanprestasi yang terjadi di travel agent dalam perjalanan luar negeri tersebut. Wanprestasi merupakan kelalaian atau kealpaan berupa :

1. Tidak melakukan apa yang sudah disanggupi atau dijanjikan di dalam perjanjian;

2. Melakukan apa yang dijanjikan tetapi tidak sesuai/maksimal sesuai dengan perjanjian;

3. Melakukan apa yang dijanjikan tetapi terlambat dalam waktu yang disepakati;

4. Melakukan sesuatu di dalam perjanjian yang dilarang/tidak boleh untuk dilakukan.

Bentuk wanprestasi yang dilakukan oleh wisatawan Indonesia tergolong pada point D. Wanprestasi dilakukan dengan cara wisatawan akan memisahkan diri dari rombongan dan menghilang pada saat tour. Mereka tidak kembali ke hotel maupun muncul dalam 24 jam sehingga dapat dinyatakan hilang dan dilaporkan hilang. Kehilangan wisatawan akan menjadi tanggungjawab travel agent. Travel agent resmi akan melalui prosedur pencatatan jumlah wisatawan saat memasuki negara tujuan wisata, begitu juga sebaliknya pada saat 
keluar dari negara tujuan wisata, jumlah wisatawan harus balanceatau sama dengan jumlah saat masuk ke negara tujuan wisata.

Kehilangan wisatawan bukanlah suatu kasus yang ringan, akan menjadi sebuah kasus yang melibatkan nama negara. Kejadian ini akan menjadi isu nasional serta memberikan citra negatif bagi travel agent. Citra negatif tersebut akan menimbulkan ketidakpercayaan masyarakat terhadap kinerja travel agent, sehingga akan berdampak pada penurunan pembelian paket wisata sampai dampak terburuk usaha tersebut gulung tikar.

Tujuan dari modus memisahkan diri dari rombongan/kabur dari rombongan tour adalah wisatawan Indonesia ingin memperoleh jalan termudah dalam meloloskan diri masuk ke negara tujuan sebagai pekerja ilegal atau imigran gelap. Perilaku ini termasuk dalam penyalahgunaan izin tinggal di luar negeri dan sebagian besar negara-negara maju di dunia menggolongkannya sebagai pelanggaran hukum serius.

Pihak imigrasi di luar negeri sangat berhati-hati dengan modus ini, sehingga wisatawan Indonesia yang ingin berpisah dari rombongan mempertimbangkan untuk menggunakan jasa perjalanan wisata dari travel agent. Apabila wisatawan Indonesia pergi sendiri, kemungkinan lolos imigrasi akan cukup sulit karena mereka tidak mampu menjelaskan dan menunjukkan bukti tempat menginap, kelengkapan dokumen dan masa waktu mereka berwisata. Fenomena penyalahgunaan visa dan kasus wisatawan Indonesia yang kabur dari rombongan ini menjadi perhatian pihak imigrasi di negara lain, tidak heran ada perlakuan yang lebih ketat terhadap wisatawan Indonesia.

Keberanian wisatawan Indonesia dalam melakukan praktik pemisahan diri dari rombongan travel agent diidentifikasi karena adanya pihak lain yang sudah siap menampung mereka di luar negeri. Salah satu destinasi yang mereka tuju menjadi tempat pertemuan/meeting point antara wisatawan Indonesia dengan pihak ketiga. Meeting point yang dipilih adalah tempat-tempat yang ramai akan wisatawan dan peluang luput dari pengawasan tour leader cukup tinggi. Praktik ini ditakutkan memiliki dampak buruk, karena pekerja ilegal akan kesulitan mendapatkan pekerjaan yang layak atau sesuai harapan. Dampak terburuk dari pekerja ilegal adalah human traffickingatau jual beli organ manusia.

\section{Penegakan Hukum terhadap Fenomena Wanprestasi Wisatawan Indonesia dalam Perjalanan Wisata Luar Negeri}

Kode Etik Pariwisata Dunia pada pasal delapan menyatakan kebebasan bergerak wisatawan, yaitu wisatawan memiliki hak untuk berwisata tanpa harus mengikuti prosedur yang berlebihan atau perlakuan diskriminatif. Apabila Kode Etik Pariwisata Dunia ini dapat dilaksanakan dengan konsisten maka akan memberikan harmonisasi bagi negara asal, negara transit dan negara tujuan pariwisata. Negara tujuan telah membuka pintu bagi Negara Kesatuan Republik Indonesia dalam hubungan soft diplomacy bidang budaya dan pariwisata. Perlu adanya sikap konsisten menjaga hubungan diplomasi baik dari pemerintah Indonesia, pengusaha travel agent Indonesia serta wisatawan Indonesia untuk menjaga kepercayaan negaranegara lain.

Perjanjian merupakan sebuah kesepakatan antara para pihak yang akan menjadi ketentuan hukum dan memiliki dampak hukum bagi para pihak yang mengikatkan diri (Subekti, 1985). Perjanjian menganut Asas Kebebasan Berkontrak, dimana isi dari perjanjian ditentukan oleh kedua belah pihak secara bebas dan seluasluasnya tetapi tetap berpedoman kepada Peraturan Perundang-Undangan, khususnya berpedoman pada Kitab Undang-Undang Hukum Perdata (Sjahdeini, 1993). Praktik wanprestasi terhadap perjanjian perjalanan wisata luar negeri dari wisatawan Indonesia sebagai pekerja ilegal merupakan kegiatan yang telah mencederai kode etik pariwisata. Apabila fenomena tersebut terjadi terusmenerus maka akan berdampak buruk bagi Negara Kesatuan Republik Indonesia

Sesuai dengan aturan di dalam Kitab Undang-Undang Hukum Perdata dijelaskan bahwa, wanprestasi merupakan sebuah kealpaan dan kelalaian para pihak yang mengikatkan diri di dalam sebuah perjanjian sehingga apabila terjadi wanprestasi tersebut dapat diperkarakan secara hukum di Pengadilan Negeri secara perdata. Perkara perdata ini dapat diperkarakan di wilayah dimana perjanjian tersebut ditandatangani. Posisi pada praktik wisatawan Indonesia yang kabur dari rombongan travel agent cukup sulit untuk diperkarakan. Pihak wisatawan 
Indonesia sebagai pelaku di dalam mencederai perjanjian merupakan orang perseorangan, sehingga tidak dapat diwakilkan oleh orang lain.

Kaburnya wisatawan Indonedia di luar negeri berdampak tavel agent tidak dapat menuntut apa-apa kecuali mereka melakukan klarifikasi kepada khalayak umum untuk mempertahankan citra positif travel agent dimata nasional dan dunia. Salah satu cara agar dapat menemukan wisatawan yang melarikan diri dari rombongan adalah melalui kepolisiandi negara tujuan wisata dan berkoordinasi dengan pihak imigrasi di negara tujuan wisata.Bantuan dapat diperoleh dari Kedutaan Besar Indonesia dan Negara Kesatuan Republik Indonesia melalui Kementerian Luar Negeri.

Langkah yang tepat dalam memperkuat keberlakuan hukum dalam Peraturan Perundang-Undangan dalam menyikapi fenomena tersebut adalah:

1. Peran Association of The Indonesia Tour and Travel Agencies (ASITA)

- Mengadakan evaluasi dan monitoring pada travel agent di Indonesia;

- Mengajak travel agent Indonesia yang belum bergabung dengan ASITA agar segera bergabung kedalam badan organisasi ASITA dengan tujuan untuk dapat mendata dan melakukan verifikasi terhadap travel agent;

- Memperketat standar operasional prosedur dalam perjalanan wisata ke luar negeri untuk travel agent Indonesia.

2. Peran Pemerintah

- Melakukan diplomasi kepada negaranegara di dunia untuk mengembalikan citra positif Negara Kesatuan Republik Indonesia;

- Pihak Imigrasi Indonesia memperketat pengajuan passport;

- Pemerintah membuat kebijakan setiap usaha tour and travel wajib menyertakan rekomendasi dari ASITA.

3. Peran Travel Agent Indonesia

- Penahanan passport bagi wisatawan selama mengikuti perjalanan wisata luar negeri;

- Adanya jaminan dana ganti rugi sebelum berangkat ke luar negeri dalam jumlah yang cukup besar atau adanya jaminan yang akan dikembalikan pada saat pulang kembali ke Indonesia;

- Memperketat dan menyeleksi calon pembeli paket perjalanan wisata luar negeri, dikhususkan bagi mereka yang sudah bekerja dan mampu menunjukkan surat keterangan bekerja untuk dapat diverifikasi;

- Memperketat data-data keluarga, seperti nomor telepon dan alamat, jika seandainya terjadi kondisi darurat

\section{SIMPULAN DAN SARAN Simpulan}

Fenomena wisatawan Indonesia yang membeli paket perjalanan wisata luar negeri di travel agent untuk dapat bepergian ke luar negeri dengan modus akan kabur setibanya di luar negeri perlu mendapat perhatian khusus dan wajib untuk ditelaah lebih dalam. Kekecewaan terhadap taraf hidup di Indonesia membuat mereka tergiur untuk menjadi imigran gelap di luar negeri. Kegiatan ini dapat membahayan citra Negara Kesatuan Indonesia secara umum dan citra travel agent pada khususnya. Perlu adanya koordinasi antara masyarakat, pemerintah dan pengusaha travel agent dalam menekan praktik atau kegiatan imigran gelap tersebut. Wanprestasi yang wisatan Indonesia lakukan sangat merugikan pihak Negara Kesatuan Republik Indonesia dan travel agent. Perlu adanya penekanan jaminan orang tua bagi anak-anak dan syarat bekerja bagi mereka yang berusia dewasa untuk menghindari wanprestasi tersebut. Kebijakan pemerintah dalam menanamkan pemahaman kebangsaan bagi masyarakat Indonesia untuk menjaga citra Negara Kesatuan Republik Indonesia di mata dunia karena satu orang saja yang melakukan perbuatan buruk makan akan dianggap sebagai kepribadian bangsa. Travel agent harus mendaftar secara resmi melalui sistem perizinan Negara Kesatuan Republik Indonesia untuk mendapatkan bantuan negara apabila dampak terburuk dari praktik hilangnya wisatawan Indonesia dapat diproses secara legal oleh negara, dan travel agent tidak bersinggungan dengan hukum negara maupun hukum internasional.

\section{Saran}

Setiap fenomena, memiliki dasar atau akar permasalahan yaitu pemerataan ekonomi 
di masyarakat antara masyarakat di kota dan pedesaan. Maka penting adanya kebijakan dalam pemerataan ekonomi untuk menekan praktik-praktik atau peluang-peluang baru yang menuntut masyarakat untuk merubah peruntungan nasib mereka di negara lain. Kebijakan dan hukum harus berjalan selaras dengan perkembangan zaman serta kebutuhan hidup masyarakat. Era digital dengan perkembangan informasi yang pesat perlu diimbangi dengan pemahaman dan intelektual masyarakat baik di kota dan pedesaan dalam memilah informasi. 


\section{Kepustakaan}

Andri Hadi. 2009. Bahan seminar "Politik Luar Negeri Indonesia: Prospek dan Tantangan dalam Era Globalisasi”. Dirjen IDP Departemen Luar Negeri RI.

Sjahdeini, Sutan Reny. 1993. Kebebasan Berkontrak dan Perlindungan yang Seimbang Bagi Para Pihak dalam Perjanjian Kredit di Indonesia. Institut Bankir Indonesia, Jakarta.

Subekti. 1985. Hukum Perjanjian. PT. Intermasa, Jakarta.

Peraturan Perundang-Undangan.

Kitab Undang-Undang Hukum Perdata Negara Kesatuan Republik Indonesia.

Kode Etik Pariwisata Dunia.

Undang-Undang No. 10 Tahun 2019 tentang Kepariwisataan. 